\title{
ANAK SEBAGAI AMANAH DARI ALLAH
}

\section{Idris}

\begin{abstract}
Mandate in the Qur'an is a duty that must be maintained by Muslims and by always asking for help from Allah SWT in order to maintain that mandate. Mandate has a broad meaning, including a variety of understandings, but the substance is that people must have a sense of responsibility for what is assumed on their shoulders. Aware that everything will be accounted before the God. Children are the gifts of Allah SWT that should be guarded, nurtured, guided, educated and also must to develop all of their potential according to their nature. On the other hand, children are the next generation of the coreligionists. Children are the most beautiful gift from god and at once be a trust (entrusted) that Allah SWT gives to every parents. Therefore, parents should be care to the needs and development of their children, so that they could be grow into healthy children, both physically and spiritually, and Berakhlaqul karimah and have a high intelligence. That how great the role of the next generation to the success of a Nation. Education of children has gained top priority. Because education is a very important factor in changing a civilization, so education cannot be separated from life. When someone blessed with a child then she/he has an obligation to fulfill the rights of the child, that was described by the Prophet in a hadith contained in the book of Tanbih al-Ghafilin. Narrated from Abu Hurairah RA The Prophet actually said: "there are three rights of the child to his/her parents; given a good name at birth, taught the Qur'an when it is intelligent (tamyiz) and married when it has found".
\end{abstract}

Keywords: children and mandate

\section{PENDAHULUAN}

Sejatinya dalam hidup manusia memerlukan yang nama perkawinan untuk meneruskan generasi baru atau seorang anak guna melangsungkan garis keturunan dan hal itu merupakan sebuah tuntutan yang terdapat dalam pola hidup berkelurga sejak dari zaman Nabi Adam sampai sekarang. Perwakinan merupakan tuntutan fitrah manusia sebagai kesatuan makhluk sosial. Keluarga merupakan sebuah lembaga terpenting dalam kehidupan kaum umat manusia pada umumnya dan manhaj 
290 | MUSAWA, Vol. 11 No. 2 Desember 2019 : 289 - 318

amal Islami khususnya. Hal Ini semua karena peran yang sangat luas dan mendalam yang dimilik ioleh keluarga, yaitu untuk menghasilkan serta menumbuhkan generasi terbaik dalam arti sehat secara jasmani dan rohani sehingga dapat menghasilkan generasi yang baik dalam membangun agama dan negara.

Maka tidak berlebihan apabila dikatakan bahwa keluarga merupakan pondasi awal dari bangunan masyarakat dan bangsa. Oleh karenanya, keselamatan dan kemurnian rumah tangga adalah faktor penentu bagi keselamatan dan kemurnian masyarakat, serta sebagai penentu kekuatan, kekokohan, dan keselamatan dari bangunan negara. Dari sini bisa diambil kesimpulan bahwa kokohnya atau tidaknya rumah tangga maka itu sebagai konsekuensi dari logisnya masyarakat serta berdampak terhadap negara yang dapat dipastikan juga turut hancur.

Keluarga merupakan satu satuan kerabat yang terbentuk dari hasil perkawinana dan mempunyai sifat mendasar terdiri dari suami, isteri serta anak. Keluarga menurut dan berada dalam pandangan Islam memiliki nilai begitu besar. Agama Bahkan Islam sangat menaruh perhatian dan pandangan yang begitu besar terhadap kehidupan tata keluarga yaitu menaruh dan meletakkan ajaran atau kaidah yang sopan serta arif untuk memelihara kehidupan keluargaserta menjaganya dari ketidak harmonisan serta kelangsungan kehancuran. Mengapa demikian besarnya perhatian agama Islam? Karena tak dapat dikesampingkan dan dipungkiri bahwa keluarga itu merupakan ibaratnya sebuah batu susunan pertama guna mendirikan serta membangun sebuah bangunan megah yang berbentuk istana dalam masyarakat muslim dan merupakan pendidikan iman yang sangat diharapkan untuk menghasilkan penerus-penerus islam yang mampu menegakan kalimat Allah dan ajaran yang dibawa oleh para Nabi di muka bumi. ${ }^{1}$

Bila pondasi ini kuat lurus agama dan akhlak anggota maka akan kuat pula masyarakat dan akan terwujud keamanan yang didambakan. Sebaliknya bila sebuah keluarga itu tercerai berai maka ikatan yang berada keluarga serta terjadi kerusakan

\footnotetext{
${ }^{1}$ Nuri, Sukamto, Petunjuk Membangun dan Membina Keluarga Menurut Ajaran Islam. (Surabaya: Al-Ikhlas, 1981).
} 
dalam haust menghasut atau meracuni para anggota terebut maka dampak terlihat pada masyarakat bagaimana kegoncangan akan terjadi dan melanda, hal tersebut dapat membuat rapuh kekuatan sehingga tidak akan tercipta rasa aman tentram dan bahagia di lingkungan tersebut.

Keluarga yang terbaik yaitu sakinah, mawaddah, wa rahmah, merupakan sebuah keluarga yang menjadi dambaan bahkan hal tersebut merupakan tujuan yang hendak dicapai dalam sebuah ikatan yang bernama perkawinan dan sakinah merupakan suatu hal yang didatangkan Allah Swt. Maka untuk mewujudkan keluarga sakinah harus melalui usaha maksimal baik melalui usaha bathiniah (memohon kepada Allah Swt), maupun berusaha secara lahiriah (berusaha untuk memenuhi ketentuan baik yang datangnya dari Allah Swt. dan Rasul-Nya, maupun peraturan yang dibuat oleh para pemimpin dalam hal ini pemerintah berupa peraturan dan perundang-undangan yang berlaku. Tujuannya Sesuai dengan Undang-Undang Nomor 1 Tahun 1974 tentang Perkawinan pasal 1 bahwa "Tujuan perkawinan adalah untuk membentuk keluarga (rumah tangga) yang bahagia dan kekal berdasarkan Ketuhanan Yang Maha Esa". Membentuk keluarga yang bahagia itu, sangat besar dan dalam penjelasannya sangat berkaitan erat dengan garis keturunan, bentuk pemeliharaan dan bentuk pendidikan (keturunan) yang menjadi hak serta kewaiban orang tua. ${ }^{2}$

Al-Qur'ān juga menyebutkan tujuan dari menikah yaitu antara lain adalah supaya memperoleh ketenangan dan membina keluarga yang penuh cinta dan kasih sayang.Pentingnya keharmonisan keluarga yang paling berpengaruh untuk pribadi dan masyarakat adalah pembentukan keluarga dan komitmen pada kebenaran. Allah dengan hikmahNya telah mempersiapkan tempat yang mulia bagi manusia untuk menetap dan tinggal dengan tentram di dalamnya. Allah Swt Berfirman dalam surah Ar Rum ayat 21:

${ }^{2}$ Hilman Hadikusuma, Hukum Perkawinan Indonesia. Semarang, Fakultas Hukum Universitas Diponegoro, 1997. 
292 | MUSAWA, Vol. 11 No. 2 Desember 2019 : 289 - 318

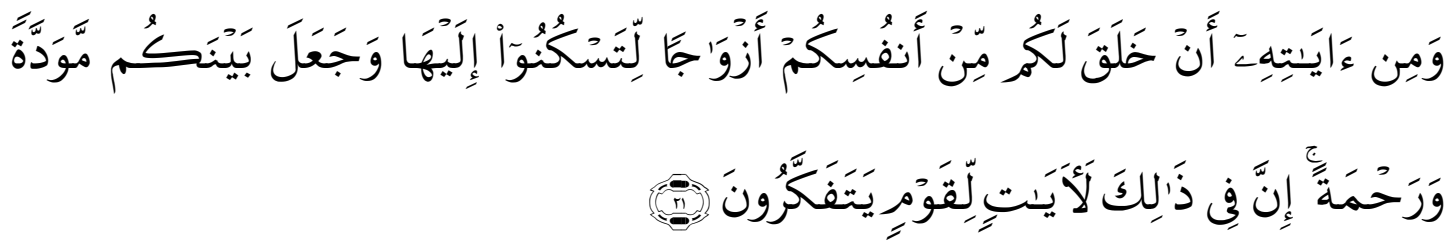

Terjemahannya

Dan di antara tanda-tanda kekuasaan-Nya ialah Dia menciptakan untukmu isteri-isteri dari jenismu sendiri, supaya kamu cenderung dan merasa tenteram kepadanya, dan dijadikan-Nya diantaramu rasa kasih dan sayang. Sesungguhnya pada yang demikian itu benar-benar terdapat tanda-tanda bagi kaum yang berfikir. ${ }^{3}$

Dalam dunia yang begitu besar dan luas ini banyak orang-orang dipercayakan mendapatkan serta memegang banyak amanah, amanah-amanah tersebut bai bersifat secara langsung dari Allah ataupun berasal sesama manusia namun dari kebanyakan sifat mereka belum mampu menerapkan sifat terpuji tersebut secara utuh pada pelaksanaan kehidupan sehari-hari. Sehingga secara benar, Amanah artinya dipercaya. Jika dipahamai secara khusus, maka amanat berarti sesuatu yang disampaikan atau yang dititipkan oleh seseorang kepadanya. Adapun makna Umum dari amanah adalah menyampaikan, memberitahu dan atau melaksanakan sesuatu yang telah di titip tugaskan kepadanya. Makna dan lawan dari sifat amanah tersebut adalah khianat atau tak dapat dipercaya.

Sebagai umat Islam, pasti telah banyak mengetahui bahwa dalam ajaran agama kita semua diwajibkan untuk mengajarkan kepada semua orang agar mampu untuk menjaga amanah apapun yang telah diberitahu atau kita terima dari orang lain. Bahkan, Islam sangat mewajibkan semua umat muslim untuk memelihara amanah, yaitu dengan cara bersikap jujur dan dapat dipercaya. Nabi Muhammad shallallahu 'alaihi wa sallam bersabda, "Kamu adalah sekalian pemimpin dan kamu sekalian kelak dimintai pertanggung-jawabannya atas apa-apa yang dipercayakan untuk kamu

${ }^{3}$ DEPAG RI, Al-Quran dan Terjemahnya, (Bandung: Al-Hikmah, Dipenogoro, 2008). 
pimpin, imam (dalam berbagai bentuk jabatan) adalah pemimpin dan ia kelak akan dimintai pertanggungjawabannya tentang apa yang telah dipimpinnya, dan seorang laki-laki (suami) merupakan pemimpin dalam lingkungan keluarga, dan ia juga akan ditanya tentang apa yang telah ia pimpin, orang wanita (istri) juga pemimpin, dalam menjaga rumah tangga suaminya, dan ia juga akan serta ditanya tentang apa yang dipimpinnya, dan seorang pembantu rumah tangga pun pemimpin dalam mengawasi dan menjaga harta benda tuannyaa, dan dia juga akan ditanya tentang apa yang ia pimpin.” (H.R. Ahmad, Muttafaq 'alaih, Abu Daud dan Tirmidzi dari Ibnu Umar). ${ }^{4}$

Berdasarkan Hadis tersebut, kita mengetahui bahwa semua manusia adalah pemimpin, yang berarti mereka memiliki amanah yang harus dijaga. Jika seseorang terlihat tidak memiliki sesuatu yang dipimpin, setidaknya dia memimpin dirinya sendiri. Artinya, Allah telah memberi amanah untuk menjaga dirinya dari semua hal yang dilarang Allah.

\section{PEMBAHASAN}

\section{Pengertian Amanah}

Amanah dapat memiliki arti dipercaya atau terpercaya. Pengertian secara umum, arti amanah adalah jujur dan benarr dapat dipercaya atau tak dapat diragukan. Dengan kata lain, jika suatu urusan diberikan pada orang yang amanah maka orang tersebut akan melaksanakannya dengan sebaik-baiknya. Kemampuan oleh seseorang dalam menjaga amanah merupakan sebuah tolak ukur terhadapa usahanya untuk menjalankan perintah Allah subhanahu wa ta'ala serta menjauhi larangannya. Tidak hanya dari segi ibadah, seseorang yang dapat bersifat amanah kelak akan memiliki dan menciptakan sebuah hubungan yang baik dengan manusia lainnya. Dia akan menjadi kebanggan untuk bisa dipercaya dan dihormati pula oleh orang-orang yang berada di sekitarnya.

${ }^{4}$ Khalid, Amru. Berakhlak Seindah Rasululloh. (Semarang: Pustaka Nuun, 2007). 
294 | MUSAWA, Vol. 11 No. 2 Desember 2019 : 289 - 318

Amanah juga merupakan salah satu sifat mulia dimiliki oleh Nabi Muhammad shallallahu 'alaihi wa sallam.Ajaran untuk bersifat amanah, sejalan dengan Firman Allah di surat An Nisa ayat 58:

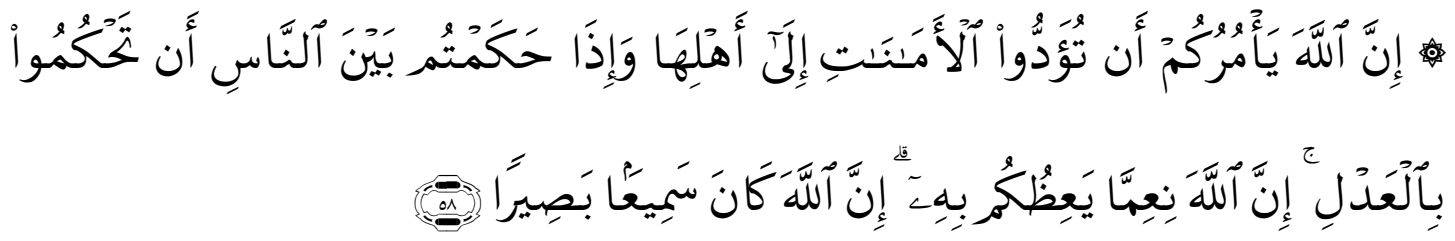

Terjemahannya:

Sesungguhnya Allah menyuruh kamu menyampaikan amanat kepada yang berhak menerimanya, dan (menyuruh kamu) apabila menetapkan hukum di antara manusia supaya kamu menetapkan dengan adil. Sesungguhnya Allah memberi pengajaran yang sebaik-baiknya kepadamu. Sesungguhnya Allah adalah Maha mendengar lagi Maha melihat.

Selain itu, Nabi Muhammad juga pernah meriwayatkan dan bersabda tentang amanah, yang disampaikan Ahmad, "Tidak ada iman yang beitu sempurna bagi orang yang tidak terdapat sifat amanah, dan tidak ada agama yang begitu sempurna bagi orang-orang tidak menepati janji".Sementara, jika dilihat dari sisi aturan dan hukum agama, amanah merupakan segala sesuatu yang kelak harus dipertanggungjawabkan dan sangat berkaitan dengan orang-orang sekitar atau pihak lain. Amanah dapat berupa benda, pekerjaan, kata, serta kepercayaan. Maka, amanah dapat berbentuk apa aja yang kelak nantinya di kemudian hari akan dimintai pertanggungjawabannya. Sebagaimana orang yang beragama Islam, kita telah mengetahui bahwa agama juga telah mendidik kita agar dapat menjaga amanah yang telah dipesankan serta diberikan dan terima dari orang lain. Bahkan, Islam sangat mewajibkan kita agar dapat memelihara amanah, yaitu berkata sesuatu dengan benar dan bertindak sesuai dengan keberana itu sendiri. 
Kompetensi seseorang dalam menjaga kepercayaan adalah tolak ukur akan usahan menjalankan perintah Allah Swt seta menjauhi apa telah dilarang olehNya.Untuk itu dalam menghindari apa yang tak boleh dikerjakan. Pelarangan tersebut Tidak hanya untuk segi ibadah, seseorang yang bersifat kepercayaan juga akan memiliki suatu keterikatan yang baik dengan mahkluk lainnya. Orang menjadi bisa dihormati dan dihargai oleh manusia lainnya di sekelilingnya. Allah Swt menempatkan sebuah kepercayaan sebagai salah satu akhlak yang memiliki tempat terbaik dan khusus bagi manusia lainnya. Bahkan, seorang manusia yang memiliki tindakan jujur bisa menjadi mahkluk yang sangat disayang Allah Swt. Seorang manusia, dan orang sekitarnya yang tak jujur dalam berbagai hal dan suka ingkar janji akan sangat dimurkai oleh Allah Swt serta suatu saat akan dijadikan contoh hukuman kepada seluruh makhluk di hari akhir nanti. Sementara itu, bila dipandang dari bagian aturan serta ajaran agama kepercayaan merupakan semua sesuatu yang wajib akan di mintai perhitungan dan berkaitan dengan manusia lain atau orang lain. Maka Kepercayaan itu bisa berupa harta, sikap, dan tindakan serta kelakukan. Maka, amanah bisa dalam segala sesuatu dan tiba masanya akhir waktu kelak akan di hitung.

Allah Swt telah menciptakan seluruh mahluk hidup yang berada dalam alam ini yakni ciptaan tersebar dilangit dan bumi untuk menandai kebesaran keindahan memperhitungkan termaksud didalamnya adalah kekayaan dan generasi selanjutnya yang akan menjadi penerus Allah berfirman dalam surah Ali Imran ayat 14:

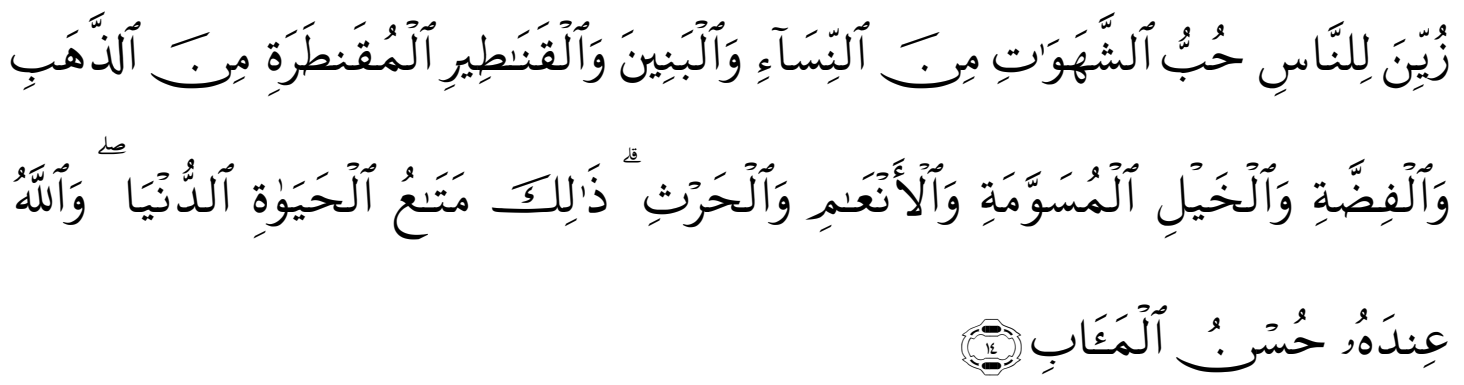


296 | MUSAWA, Vol. 11 No. 2 Desember 2019 : 289 - 318

Terjemahnya:

Dijadikan indah pada (pandangan) manusia kecintaan kepada apa-apa yang diingini, Yaitu: wanita-wanita, anak-anak, harta yang banyak dari jenis emas, perak, kuda pilihan, binatang-binatang ternak dan sawah ladang. Itulah kesenangan hidup di dunia, dan di sisi Allah-lah tempat kembali yang baik (surga). ${ }^{5}$

Anak merupakan karunia dan hibah dari Allah Subhanahu wa Ta'ala sebagai penyejuk pandangan mata, kebanggaan orang tua dan sekaligus perhiasan dunia, serta belahan jiwa yang berjalan di muka bumi. Allah Subhanahu wa Ta'ala berfirman.dalam surah Al Kahfi ayat 46:

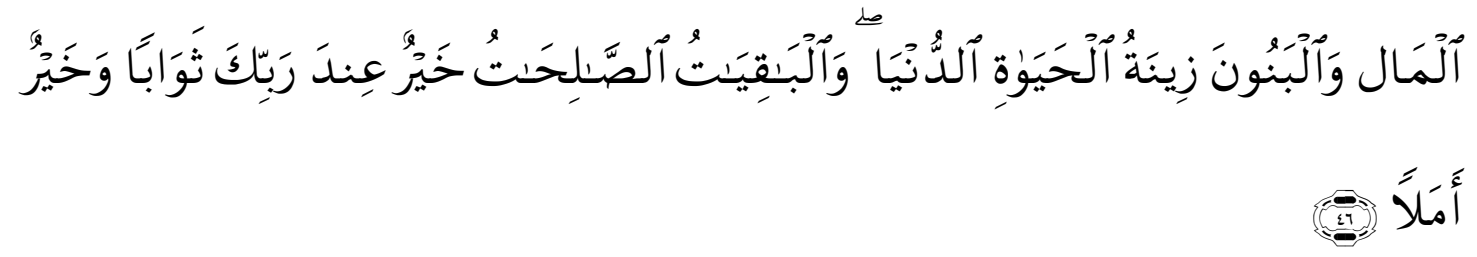

Terjemahnya:

Harta dan anak-anak adalah perhiasan kehidupan dunia tetapi amalan-amalan yang kekal lagi saleh adalah lebih baik pahalanya di sisi Tuhanmu serta lebih baik untuk menjadi harapan.

Amanah merupakan sesuatu yang sangat Mutlak sifatnya untuk dilaksanakan dan di penuhi, karena amanah tersebut kelak akan di bawa dalam kehidupan lain, sebagai salah satu hal yang akan di mintai pertanggungjawabannya.

\section{Macam-macam Amanah}

\section{1. kepercayaan dalam menjaga sesuatu yang telah diberikan dan akan dikembalikan ketiba waktunya.}

Pesanan yang disampaikan oleh seseorang menggambarkan siapa kita yang sebenarnya dan itu merupakan sebuah kepercayaan. Oleh sebab itu, apa yang telah dititipkan oleh seseorang buat akita yang berupa sebuh kepercayaan harus dipelihara

${ }^{5}$ Departemen Agama RI, Al-Qur'an dan Terjemahnya. 
agar tidak ada yang berkurang atau hilang. Sehingga ketika tiba waktu dari titipan tersebut kita dapat memberikannya kembali tanpa ada sesuatu yang berubah atau kurang.

\section{2. kepercayaan dalam menjaga suatu pesan tertentu}

Sebuah pesan tertentu yang disampaikan kepada kita dan dimana hal tersebut tak semua orang untuk harus mengetahuinya, Karena itu sudah merupakan sebuah kepercayaan maka dari hal tersebut menjadi sebuah kewajiban bagi kita untuk menyimpan rapat - rapat dan bersifat tertutup dari segala sesutu yang tak berhak untuk mendengar dan mengetahui pesan tersebut

\section{Kepercayaan untuk menjaga sebuah kedudukan dan pangkat}

Kedudukan atau sebuah pangkat adalah salah satu bentuk kepercayaan yang harus dijaga dan dipegang secara bijak, baik dan terencana sesuai dengan undangundang. Atas dasar tersebut maka, seseorang yang telah mempunyai kedudukan tetap agar tidak melakukan tindakan atau melanggar ketetapan yang telah ada dan bersifat wajib. Karena jika sesorang tersebut telah berbuat sesuatu yang melanggar amanah tersebut, maka orang itu telah berbuat lalim, kejam dan sangat berdoa terhadap sesgla sesautu yang telah di ciptakan oleh Sang Maha Pencipta.

\section{Amanah dalam melaksanakan tanggung jawab}

Kita sebagai mahluk ciptan Allah Swt yang paling sempurna diantara berbagai Ciptaan-Nya yang berada diatas bumi ini hendaknya selalu menjadi seorang yang sopan, bertutur kata yang ramah, berkepribdian yang baik, berperangai yang santun karena suatu saat akan menyandang berbagai predikat sebagai Istri, suami anak, pangkat dan kedudukan lainnya dalam pemerintahan dan masyarakat. Menjadi siapapun dalam ini nanti, suatu saat kita juga akan mempunyai tanggung jawab yang harus kita tunaikan.akan tiba masa dimana akan di perlihatkan kepada kita atas apa yang telah diperbuat dan seluruhnya itu dipertanggung jawabkan kelak di kemudian hari. 
298 | MUSAWA, Vol. 11 No. 2 Desember 2019 : 289 - 318

\section{Kepercayaan dalam menjaga keyakinan.}

Menjalani sesuatu yang telah diyakini atau menjadi keyakinan dalam diri, merupakan suatu hal paling utama. Pola - pola pendidikan serta pengajaran tersebut merupakan sesuatu yang harus dan sesuadahnya diperlukan pengaplikasian kepada khalayak umum. Atas dasar hal itulah segala sesuatu yang ditelahdi ketahui dan pelajari, serta dipahami akan kebenaran ajaran tersebut kelak akan diperhitungkan dihadapan Allah Swt, Sebagaimana Sabda Nabi SAW yang artinya: "Sampaikanlah pesanku kepada manusia meskipun hanya satu ayat". HR. Ahmad maka dalam menjaga rahasia atau sebuah kepercayaan dengan sungguh-sungguh akan dapat menghapuskan kesalahan kesalahan dari tingkah laku yang pernah diperbuat.

\section{6. kepercayaan dalam berdagang}

Di antara jenis kepercayaan atau keihklasan lain terdapat pula dalam hal berdagang antara seorang Penjual dan pembeli jual beli serta pada dalam bidang kegiatan kita lainnya. Dalam bidang pekerjaan orang lain terdapat juga kepercayaan yang juga sama penting untuk di pelihara dan hal tersebut merupakan suatu bentuk tanggung jawab dan sesuatu yang tidak untuk dilalaikan.

Ibaratnya sebuah kepercayaan merupakan rangkaian dari sistem langit dan bumi jika langit tak ada atau hilang maka bumi tak lengkap,pun sebaliknya jika kepercayaan tak dpegang sepenuh hati maka malapetaka akan menimpa. Maka dari hal tersebut sangat wajib dalam ememgang kepercayaan baik dalam waktu masih bernafas ataupun tak lagi bernafas Sebagaimana Rasul SAW bersabda ada empat masalah yang terjadi, jika mampu melaksanakan atau memegangnya niscaya selalu berkecukupan segala hal di alam ini,yakni, mampu memegang rahasia, berbicara apa adanya, bersikap layak dan mampu menjga diri saat susah. ${ }^{6}$

Menjadi bagian dalam kekuasaan ciptaan Allah Swt, maka setiap individu dalam dirinya terdapat kemampuan dalam dirinya untuk menerima kepercayaan

\footnotetext{
${ }^{6}$ Notowidagdo, Rohiman, Ilmu Budaya Dasar Berdasarkan Al Qur'an dan Hadits. (Jakarta: Raja Grafindo Persada, 2000).
} 
.tetapi kemampuan ini mempunya dua buah pandangan baik bersifat positif maupun negatif. Terdapatnya hal tersebut menjadikan setiap orang tersebut memerlukan sebuah pandangan atau sebuah petunjuk guna menegmbalikn mereka pada kebesaran Allah SWT. Berbeda dengan langit, bumi dan gunung-gunung yang hanya bisa patuh (dalam tafsir al-Mishbah, maksud penolakan makhluk-makhluk tersebut adalah karena ketiadaan potensi untuk menanggung amanah), manusia memiliki kehendak bebas, yang menyebabkan kemungkinan terjadinya banyak kesalahan. Sesungguhnya Allah SWT. sangat mengenal ciptaan-Nya seperti manusia dan yang lain-lainnya. Kemampuan yng ada dalam diri setiap makhluk dapat disebut Insan hal ini sebagaimana firman Allah dalam Al-Quran dalam surah Al-Insan ayat 1:

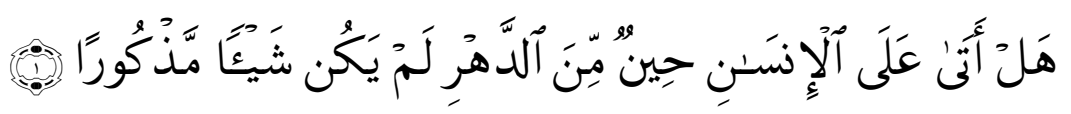

Terjemahannya

Bukankah telah datang atas manusia satu waktu dari masa, sedang Dia ketika itu belum merupakan sesuatu yang dapat disebut?

\section{Anak adalah Amanah Allah}

Anak adalah amanah Allah yang dititipkan kepada orangtua dan akan ditanyakan pertanggungjawabannya, maka menjadi kewajiban orangtua untuk mendidiknya dengan baik agar menjadi generasi yang berkualitas. Sebuah hadist dari Nabi: tak ada pemberian apa pun yang sangat utama berasal orang tua pada anak selain pendidikan terbaik (H.R. Hakim dan Baihaqi) Amanah yang disia-siakan, tentulah menyebabkan kehancuran peradaban. Anak adalah amanah yang diberikan Oleh Allah Swt kepada orang tua guna sebagai penerus untuk kehidupan selanjutnya. Di antara bentuk ketakwaan seorang hamba kepada Allah Subhanahu wa Ta'ala adalah dengan menjalankan dan menjaga amanah yang dipikulnya. Baik amanah yang berkaitan dengan kewajiban kepada Allah Subhanahu wa Ta'ala seperti shalat, berwudhu, membayar zakat dan yang lainnya, maupun yang berkaitan Dengan 
300 | MUSAWA, Vol. 11 No. 2 Desember 2019 : 289 - 318

hubungan kepada sesama mahluk ciptaan Allah Swt, untuk itu diperlukan sebuah pemahaman tentang makna dari sebuah kepercayaan atau titipan bahwa hal tersebut sangat luar arti dan tujuannya.Setip kepercayaan yang diberikan kepda seseorang tidak sellu sama dengan orang lain. Namun, ketika akan ditanyai tentng apa yang telah dilakukan dan di perbuat di hari akhir dihadapan Allah Swt atas pelaksanaan amanah yang diembannya. Perlu diketahui bahwa dalam menjalan sebuah amanh dan untuk dapat melakukan bukan sebuah hal yang mudah.

Seorang anak adalah karunia besar Dari Allah Swt yang diberika kepda pasangan suami istri .Tidak semua orang dapat memiliki anak. Tidak jarang pasangan yang belum dikarunia anak pun akan melakukan berbagai usaha demi mendapatkan anak.semua pasangan akan berusaha dengan segala cara untuk mempunyai anak keturunan, Karena rumah tanpa anak akan terasa sepi dan tak berwarna. Oleh karena itu, dengan keberadaannya harus disyukuri, karena mensyukuri nikmat adalah perintah Allah swt.

Buah hati atau biasa disebut anak, merupakan generasi penerus sebuah keluarga. Sebagaimana yang diceritakan Sayyidina Ali Zainal Abidin kapan saja beliau menerima berita tentang kelahiran anak, beliau tak pernah mempertanyakan apakah anak itu laki-laki maupun perempuan. Beliau biasa memanjatkan doa ketika memeperoleh kabar bahwa anak itu sehat wal afiat. Anak adalah tanggung jawab orang tua oleh karena itu, anak harus mendapatkan pelayanan dan pendidikan yang baik agar anak tumbuh menjadi generasi yang diharapkan. Anak adalah sebuah karunai yang diberikan Allah Swt dan sesuatu paling penting pelihara, dirawat dan dididik. Jika orang tua berhasil dalam merawat menjaga, dan mendidiknya secara benar dan terarah maka anak tersebut akan menjadi penenang jiwa dan penyejuk hatinya. Dalam al-Quran Allah swt menjelaskan tentang jenis dan cara hidup di antara manusia pilihan-Nya, di mana salah satu pola hidup mereka adalah senantiasa berdoa agar memiliki anak keturunan yang akan menjadi pelipur lara dan pemberi senyuman. sebagaimana telah disebutkan dalam Al Qur'an Surat Al-Furqan Ayat 74 


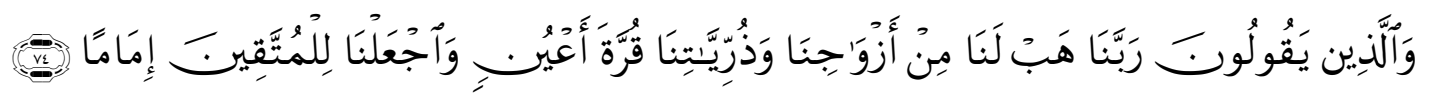

Terjemahnya:

Dan orang orang yang berkata: "Ya Tuhan Kami, anugrahkanlah kepada Kami isteri-isteri Kami dan keturunan Kami sebagai penyenang hati (Kami), dan Jadikanlah Kami imam bagi orang-orang yang bertakwa.

Dengan demikian tentang keberadaan anak itu sendiri akan menjadi penyejuk dan penenang jiwa orang tua, lebih utama pada waktu masih bayi terkesan lucu usia dini.Keberadaannya, semua pola tingkah laku, kelucuannya, akan menjadi rasa penghialng lelah bagi orang tua dan penghilang rasa jenuh akibat aktivitas sehari.Bahkan pula tak jarang orang tua sibuk dengan berbagai kegiatan dan pekerjaan serta rutinitas selalu berusaha mengatur waktu hanya untuk sekadar refreshing ia akan bermain dan bercanda bersama anaknya. ${ }^{7}$

Dengan andanya bekal pendidikan yang baik dari orang tua terhadap anak nya, maka secara tidak langsung telah mengantisipasi problematika generasi mendatang. Termasuk dari menjaga amanah adalah yang berkaitan dengan pendidikan. Seorang orang tua harus berusaha menjaga amanah yang dipikulnya. Dia harus berusaha untuk menjadi contoh yang baik bagi anak anaknya. Karena terkadang anak lebih banyak melihat kepada sikap dan tingkah laku daripada apa yang disampaikan kepada mereka. Begitu pula dia berusaha menyampaikan ilmu yang bermanfaat dengan cara yang mudah dipahami oleh anaknya serta tidak memaksakan diri untuk menyampaikan pelajaran yang belum dikuasainya yang berakibat dirinya akan terjatuh pada perbuatan "berbicara tanpa ilmu". Terutama yang terkait dengan masalah agama. Semuanya harus dilakukan dengan menjaga amanah. Pendidikan merupakan hal yang utama di berikan kepada anak sejak belia sebagaimana Kisah

\footnotetext{
${ }^{7}$ https://icc-jakarta.com/2018/07/25/anak-anugerah-sekaligus-amanah-allah-swt/
} 
302 | MUSAWA, Vol. 11 No. 2 Desember 2019 : 289 - 318

Lukmanul hakim dalam mengajarkan pendidikan moral yang terkisah dalam Al Qur'an surah Al-Lukman Ayat 16:

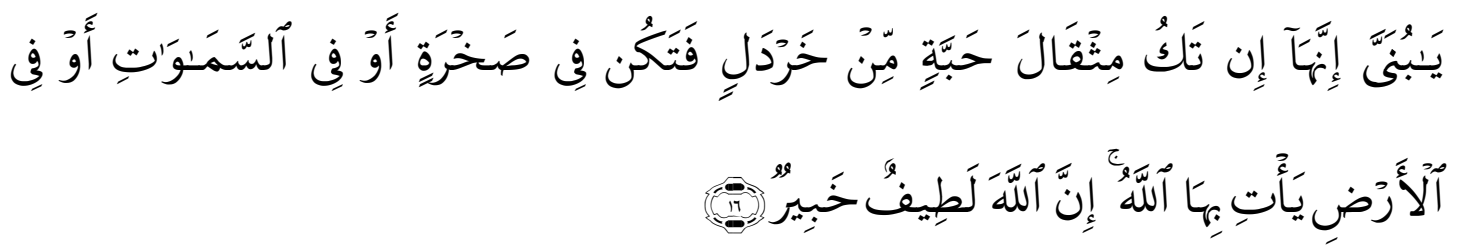

Terjemahannya

(Luqman berkata): "Hai anakku, Sesungguhnya jika ada (sesuatu perbuatan) seberat biji sawi, dan berada dalam batu atau di langit atau di dalam bumi, niscaya Allah akan mendatangkannya (membalasinya). Sesungguhnya Allah Maha Halus lagi Maha mengetahui.

Sudah semestinya bagi seorang suami atau pemimpin dalam rumah tangga dapat menjaga keluarganya dari berbagai hal yang dapat membahayakan mereka baik berkaitan dengan urusan dunia serta akhiratnya. Terlebih juga saat kerusakan serta kemaksiatan sudah tersebar di mana-mana. setiap orang tentu lebih berusaha menjaga hartanya ketika dia mendengar bahwa terjadi pencurian atau pun semisalnya yang tengah merajalela. Bahkan, untuk menjaga keluarga serta anak-anaknya dari berbagai kerusakan di sekitarnya semestinya lebih diutamakan dari melindungi harta. Karena, ketika melalaikan kewajiban maka dapat menyebabkan munculnya satu generasi mendatang yang akan berbuat kerusakan dimuka bumi. Demikian Juga setiap orang tua tentu tidak menginginkan hanya dirinya yang masuk ke dalam surga sementara anaknya diazab dineraka. Oleh karena itu, sudah semestinya kita semua berusaha menjaga amanah ini, sehingga mudah-mudahan Allah Swt menyelamatkan kita semua serta keluarga dan orang sekitar kita dari api neraka bahkan mengumpulkan kita, keluarga kita di dalam surga-Nya.

Anak adalah perhiasan hidup di dunia kekuatan keagungan dn benteng pertahanan. Selain itu mereka adalah penenng jiwa dan penyenang hati. Ini lah tiga yang jenyataan yang disuratkan dalam firman Allah Swt yang telah dapat kita rasakan gambaran, rinciannya dan kita rasakan kebenaraannya. Oleh karena itu, sudah 
seharusnya orng tua memperhatikan pendidikan anak-anaknya, sehingga kebahagiaan mereka dpat diwujudkan dengan diwarnai perhiasan hidup dan mereka selalu gembira.

Perhatian terhadap anak-anak oleh syariat Islam telah dimulai sejak mereka sebelum dilahirkan, yaitu ketika Rasul yang mulia memerintahkan kaum muslimin untuk mencari calon suami atau istri yang baik. Kriteria calon pasangan hidup harus didasarkan atas asas takwa dan kesalihan, jelas nasabnya dan kehormatn para calon itu. Perkawinan yang didasarkan atas asas inilah yang antinya akan melahirkan anak anak yang suci dari segala segi, tercetak dengan akhlak Islam yang mulia serta adat istiadat hidup berumah tangga yang bahagia. Anak anak itu akan mengisap dan menyedot susu kemulian dan keutamaan dari para orang tua mereka dan secara alami mencerap sifat - sifat yang baik dan perilaku - perilaku yang mulia Rasulullah bersabda "Manusia adalah barang tambang. Manusia terbaik di zaman jahiliyah dia juga yang terbaik setelah masuk Islam, apabila dia paham agama." (HR. Bukhari)

Ketika Seseorang telah dikaruniai anak sudah seharusnya untuk memenuhi kewajiban dan memberikan hak anak yang dijelaskaan oleh Nabi di dalam sebuah hadis yang terdapat dalam kitab Tanbih al-Ghafilin.. Diriwayatkan dari Abu Hurairah ra Sesungguhnya Nabi Saw bersabda : Seorang anak mendapatkan tiga hak atas orang tuanya yaitu memberi sebuah nama terbaik setelah lahir, kemudian memberikan pengajaran ilmu agama al-Quran ketika sudah berakal ( tamyiz) serta menikahkanya ketika menemukan jodoh. Berdasarkan hadis tersebut 3 hak anak adalah:

\section{1. memberi nama yang baik.}

Karena Sebuah nama yang berikan oleh orang tua didalamnya terselip yang juga merupakan sebuah doa serta terdapat harapan yaitu kelak sianak apakah dapat menjadi orang yang dibanggakan. Dan didalam sebuah nama yang baik juga dapat menumbuh kembangkan serta dapat menambahkan rasa percaya diri anak. Nama terbaik bagi pria adalah memberi awalan nama dengan nama Muhammad atau bisa dengan mengambil nama orang-orang sholeh dan lain sebagainya. Sedangkan 
304 | MUSAWA, Vol. 11 No. 2 Desember 2019 : 289 - 318

nama bagi anak wanita bisa mengambil nama putri-putri Rasul dan atau istri beliau bahkan nama -nama yang lain namun memiliki arti yang baik.

\section{Mengajarkan al-Quran jika sudah berakal (tamyiiz).}

Yaitu Apabila seorang anak mulai dapat berfikir serta menerima ilmu, orang tua sudah wajib menghadirkan sebuah pelajaran bagaimana adab serta tata cara membaca al-Quran dan serta apa makna yang terdapat dan tersirat pada ayat-ayat Al-Qur'an. bahkan Selain hal tersebut, seorang anak harus berikakn pengetahun tentang ilmu fikih serta ilmu agama lainnya untuk sebagai pedoman mereka dan keluarga anak-anaknya untuk melaksanakan ajaran dan anjuran ibadah. Memberikan pendidikan anak ilmu agama tidak harus dilakukan seorang diri tetapi dapat pula memasukkan anak ke sekolah-sekolah yang mana di dalamnya mengajarkan ilmu agama.

\section{Menikahkanya jika sudah menemukan pasangan.}

Yaitu dengan tidak mempersulitnya dalam melangsungkan pernikahan dan membantunya jika membutuhkan bantuann untuk pelaksanaannya. Tentu saja demikian itu jika sudah mendapatkan pasangan yang sekufu' denganya agar anak tidak terjerumus dalam kemaksiatan.

Sesuai dengan hadist diatas yang memberikan hak anak atas orang tuannya maka uratan yang pertama adalah memberikan nama. Hal ini sesuai dengan Hadist Rasulullah yaitu Dari Samuroh bin Jundub, Rasul Saw bersabda: 'Setiap anak tergadaikan dengan aqiqahnya, disembelihkan untuknya pada hari ke tujuh, digundul rambutnya dan diberi nama'." HR. Abu Daud

Aqiqah adalah suatu rangkaian kegiatan merayakan kelahiran anak dengan menyembelih binatang yang dilakukan pada hari ketujuh, lalu dagingnya disedekahkan pada fakir miskin bersamaan dengan mencukur rambut kepala anak serta memberikan nama anak. Aqiqah cukup populer ditengah-tengah masyarakat Indonesia. Aqiqah merupakan bentuk rasa bersyukur atas nikmat yang diberikan Allah SWT kepada hambanya dalam bentuk rizki seorang anak. Dengan memproleh 
rezeki itu nikmat itu, keluarga yang telah menunaikan kegiatan aqiqah anak diharapkan untuk dapat berbagi kegembiraan kepada para saudara, kerabat, tetangga, dan teman dekat sehingga menumbuhkan ikatan rasa cinta kasih. ${ }^{8}$

Islam menganjurkan agar para orang tua agar memberikan nama kepada anaknya dengan benar dan baik, karena menurut Islam nama adalah sebuah do'a. Melihat pentingnya dan besarnya arti sebuah nama maka, pemberian nama dalam Islam pun tidak boleh sembarangan. Islam sangat menganjurkan aturan atau tata cara untuk memberi nama anak, sehingga para orang tua tidak salah dalam memberikan nama anak-anaknya, karena dengan nama sedikit banyak memberi mempengaruhi bagi kehidupan anak. Oleh karena itu sangat dianjurkan agar para orang tua memberikan anaknya nama dengan arti yang bagus, dan juga indah untuk dipanggil.

Pemberian nama yang baik untuk anak-anak dapat dilakukan sambil melaksanakan aqiqah. "Rasulullah sangat menaruh dan memberi perhatian yang sangat besar terhadap masalah nama. Kapan saja saat beliau menjumpai nama tidak sesuai (patut) dan tak berarti, beliau langsung mengubahnya dan memilih sejumlah nama yang pantas. Beliau mengganti macam-macam nama laki-laki dan perempuan. Seperti dalam hadis yang disampaikan oleh Aisyah radhiyallahu 'anha bahwa Rasulullah shallallahu'alaihi wa sallam biasa mengubah nama-nama yang tidak baik." (HR Tirmidzi) bahkan Diketahui bahwa Rasulullah SAW memberi perhatian yang begitu besar terkait nama. Rasulullah sangatlah menyukai nama yang baik. Beliau tak akan membiarkan nama yang tak pantas untuk seseorang, suatu daerah serta sebuah kota. pada suata daerah terdapat Nama seseorang semula bernama Ashiyah, yang artinya yang suka bermaksiat telah dirubah langsung dengan Jamilah bermakna atau arti cantik. Rasul Saw bersabda, Sesungguhnya kamu sekalian akan dipanggil pada hari kiamat dengan nama-nama kamu sekalian, perbaguslah nama kalian. (HR.Abu Dawud). Oleh karena itu, memperbagus nama sangat dianjurkan.

${ }^{8}$ M. Nipan Abdul Halim, Mendidik Keshalehan Anak (Akikah, Pemberian Nama, Khitan dan Maknanya), (Jakarta: Pustaka Amani, 2001). h. 4. 
306 | MUSAWA, Vol. 11 No. 2 Desember 2019 : 289 - 318

Nama-nama yang paling utama adalah nama - nama para Nabi atau nama Abd yang dirangkaiian dengan nama Allah Swt, seperti Abdal- Rahman, Abd Al- Rahim, dan harus menghindari nama Abd yang dirangkaikan dengan selain nama Allahseperti Abd A-“uzza, Abd, Al ka'bah dan lain sebagainya. Selain itu juga dilarang menggunakan nama- nama yang cabul dan tidak pantas. Nama - nama tersebut seperti Hayyam, Hayfa, Nahhad, Susan Miyadah, Nariman, Ghadah, dan Ahlam. Begitu pula, janganlah digunakan nama-nama sejenisnya yang bersal dari kata- kata yang mengandung pesimistis, sehingga bayi yang dilahirkantidak terpengaruh dengan jeleknya nama-nama tersebut, seperti Huzn dan Jumrah. Dilarang juga menggunakan nama-nama khusus untuk Allah Swt seperti , Al-Ahad, Al-Shamad, AlKhaliq, Al-Razzaq, atau dilarang juga nama-nama yang mengandung angan-angan tinggi dan susah disebut sehingga orang-orang akan memanggil namanya dengan menambahkan kata La yang berarti tidak seperti Anfa, NAfi dan Aflah.

Rasulullah Nabi Saw bersabda: berilah (anak-anakmu) dengan nama- para Nabi. Sedang dari nama yang paling disukai Allah ialah Abdullah dan Abdurrahman, sedang nama yang paling benar adalah Harits dan Hammam, Nama yang paling buruk adalah Harb dan Murrah," (HR.Abu Dawud dan Al Nasai. Sementara pada Hadist yang lain Nabi Saw bersabda Sesungguhnya dari sesuatu atau beberapa nama yang sangat dibenci oleh Allah Swt terdapat pada nama-nama yaitu seseorang yang bernama Malakul Amlak (raja diraja), (HR. Bukhori \& Muslim). ${ }^{9}$

Merawat anak dengan penuh kasih sayang, sebagai amanat yang dititipkan Allah kepada orang tua anak wajib dirawat, dibesarkan, dan diasuh dengan penuh kasih sayang. Salah satunya cara yang baik adalah dengan memberikan asupan makanan bernutrisi serta bergizi. Melalui makanan tersebut, anak akan dapat tumbuh sehat dan cerdas.

\footnotetext{
${ }^{9}$ Mahmud Al- Shabbagh, Tuntunan Keluarga Bahagia Menurut Islam. (Bandung: Remaja Rosdakarya, 2002).
} 
Dalam pendidikan Islam, seorang ibu selalu dibimbing untuk menyusui anaknya, agar menyusui si anak sampai berumur dua tahun. Mulai kelahiran sianak tersebut sampai mencapai umur dua tahun, hendaknya anak selalu diberikan air susu ibu (ASI), tapi bukan makanan lainnya. Panduan tentang menyusui anak ini tertuang dalam firman Allah dalam Q.S. Al-Baqarah ayat 233:

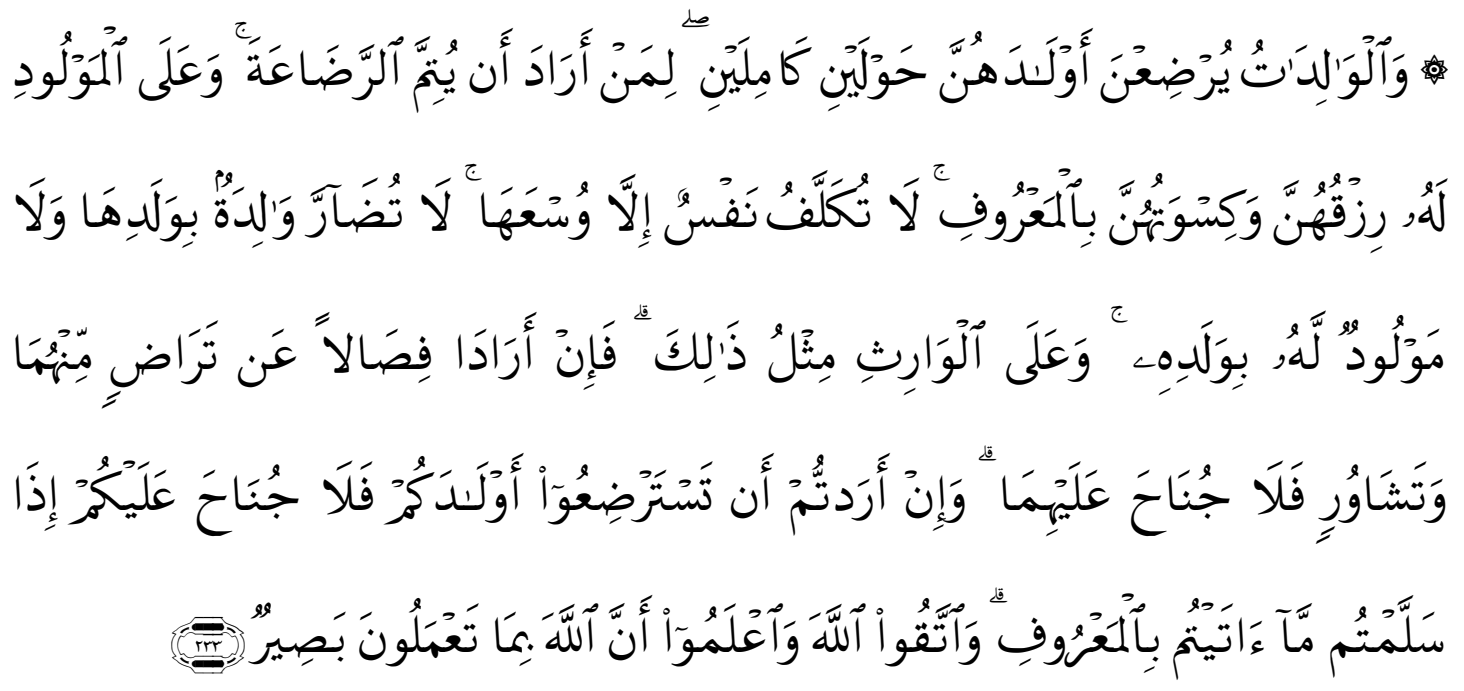

Terjemahannya

Para ibu hendaklah menyusukan anak-anaknya selama dua tahun penuh, Yaitu bagi yang ingin menyempurnakan penyusuan. dan kewajiban ayah memberi Makan dan pakaian kepada Para ibu dengan cara ma'ruf. seseorang tidak dibebani melainkan menurut kadar kesanggupannya. janganlah seorang ibu menderita kesengsaraan karena anaknya dan seorang ayah karena anaknya, dan warispun berkewajiban demikian. apabila keduanya ingin menyapih (sebelum dua tahun) dengan kerelaan keduanya dan permusyawaratan, Maka tidak ada dosa atas keduanya. dan jika kamu ingin anakmu disusukan oleh orang lain, Maka tidak ada dosa bagimu apabila kamu memberikan pembayaran menurut yang patut. bertakwalah kamu kepada Allah dan ketahuilah bahwa Allah Maha melihat apa yang kamu kerjakan.

Pendidikan merupakan salah satu hal terpenting dalam kehidupan kita. Semua orang tanpa terkecuali berhak untuk menikmati dan mendapatkan pendidikan, dimana 
308 | MUSAWA, Vol. 11 No. 2 Desember 2019 : 289 - 318

dalam tersebut tercantum dalam pasal 31 UUD 1945. Dengan demikian, tidak ada seorang pun yang dapat menghalangi siapapun untuk menempuh pendidikan yang setinggi-tingginya. Banyak pendapat para ahli filsafat, tentang arti dari pendidikan. Tetapi secara garis besar pendidikan adalah usaha sadar untuk mengembangkan kepribadian dan kemampuan baik didalam dan diluar sekolah bahkan berlangsung seumur hidup. Pendidikan yang diterima tidak hanya pendidikan formal saja, tetapi juga pendidikan in-formal, dan pendidikan non-formal.

Untuk Memahami tumbuh perkembangan anak dilakukan melalui interaksi dan interdependensi orangtua dan guru yang terus dilakukan agar penggalian kemampuan kecerdasan anak dapat dicapai secara optimal. hubungan dilakukan melalui kerjasama guru dan orangtua tuk umemahami perkembangan anak dan kemampuan dasar minimal yang perlu dimiliki anak, yaitu musikal, kinestetik tubuh, logika matematika, linguistik, spasial, interpersonal dan intrapersonal, karena pada umumnya semua orang punya tujuh intelegensi itu, tentu dengan bervariasi tingkat skala penguasaannya.Masyarakat yang menjadi lingkungan anak menjalani aktivitas sosialnya mempunyai peran yang besar dalam mempengaruhi baik buruknya proses pendidikan, karena anak satu bagian yang tidak terpisahkan dari masyarakat. Interaksi dalam lingkungan ini sangat diperlukan dan berpengaruh dalam pertumbuhan dan perkembangan anak, baik secara fisik maupun biologis.

Selain pendidikan umum seorang anak juga harus mendapat pendidikan

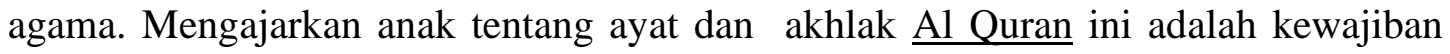
ibu dan bapak. Hadits Rasul Saw yang diriwayatkan oleh Ali ra Ajarkanlah tiga hal buat anak-anak mu, yaitu mencintai nabi kalian, mencintai keluarganya dan membaca Al Qur'an. Sebab, para pengusung Al Qur'an berada di bawah naungan arsy Allah pada hari dimana tidak ada naungan kecuali naunganNya, bersama para nabi dan orang-orang pilihanNya. Bersama mereka pula orang tua yang memperhatikan pengajaran Al Qur'an kepada anak-anaknya,keduanya mendapatkan pahala yang besar." Seperti yang dihadistkan oleh Nabi Saw."Seseorang mendidik anaknya itu 
lebih baik baginya dari pada ia menshadaqahkan (setiap hari) satu sha'." Hadis ini diriwayatkan oleh imam At-Tirmidzi dari sahabat Jabir bin Samurah r.a.

Dalam perjalanan dari masa ke masa yang semakin modern, kesulitan dan tuntutan untuk bertahan hidup membuat seorang suami dan ayah harus berjuang lebih keras dalam ibadah menafkahi keluarganya. Otomatis membuat waktu yang tersedia untuk keluarga terutama anak sering terlalaikan. sering terlalaikan. Dalam proses pendidikan buat anak perlu kerjasama dan berbagi peran. Namun proses mendidik lebih banyak bergeser ke peran ibu. Secara logika waktu seorang ibu untuk anaknya (dengan status murni ibu rumah tangga) waktu tersebut banyak dimiliki dan nyata jauh lebih banyak dibandingkan seorang ayah dimana harus beredar diluar rumah guna mencari nafkah. Tanggung jawab pendidikan anak sejatinya harus ditangani oleh kedua orang tua. Para pendidik atau guru yang berada di sekolah-sekolah, hanya sebagai partner bagi orang tua dalam proses pendidikan anak. Dalam sebuah hadits,Nabi Muhammad Saw pernah bersabda, Seorang bapak yang mendidik anakanaknya adalah lebih baik dibandingkan bersedekah sebesar 1 sa' di jalan Allah. Artinya, dengan kondisi seperti saat ini yang sudah jauh berbeda dibandingkan dengan zaman Rasullulah, pekerjaan mendidik anak sebagai bagian dari amanah Allah SWT adalah pekerjaan bersama bagi seorang ayah dan ibu.

Orang tua yang berusaha keras mendidik anaknya dalam lingkungan ketaatan kepada Allah, maka pendidikan yang diberikannya tersebut merupakan pemberian yang berharga bagi sang anak, meski terkadang hal itu jarang disadari.pendidikan dari keluarga merupakan sebagaimana Pelajaran berharga telah tergambar sebagai mana Firman Allah yang termuat dalam Al qur'an pada QS. Luqman ayat 13

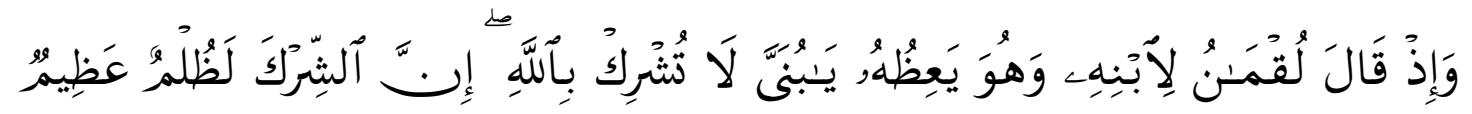

Terjemahannya 
310 | MUSAWA, Vol. 11 No. 2 Desember 2019 : 289 - 318

Dan (ingatlah) ketika Luqman berkata kepada anaknya, di waktu ia memberi pelajaran kepadanya: "Hai anakku, janganlah kamu mempersekutukan Allah, Sesungguhnya mempersekutukan (Allah) adalah benar-benar kezaliman yang besar".

Sungguh beruntung serta berbahagialah orang tua yang sukses mendidik anakanak mereka sehingga menjadi anak yang shalih, selalu membantu orang tuanya, mendo'akan orang tuanya, membahagiakan, serta mampu menjaga nama baik kedua orang tua. Karena anak shalih akan senantiasa menjadi lumbung pahala, sehingga orang tua mendapat aliran pahala dari anak shalih yang dimilikinya.Rasulullah shallallahu 'alaihi wa sallam bersabda,ketika seorang telah meninggal dunia, maka seluruh amalnya terputus kecuali tiga hal yaitu, sedekah jariyah, ilmu yang bermanfaat serta anak shalih yang mendo'a kan kedua orang tuannya. HR. Muslim

Ali Bin Abi Thalib berkata: sebaik-baiknya yang diwariskan oleh ayah kepada anaknya adalah pendidikan. Ibn Mas'ud berkata setiap pendidik sangat senang untuk diadili bersama dengan didikannya dan sesungguhnya pendidikan yang berasal dari Allah Swt adalah Al Qur'an. Dari riwayat tersebut sangat jelas untuk diketahui bahwa penanaman dan peletakan nilai-nilai agama pada masa kecil merupakan dasar pendidikan islam yang terbaikm Ali Bin Abi Thalib berkata: sebaik-baiknya yang diwariskan oleh bapak kepada anak adalah pendidikan.” Ibn Mas'ud berkata setiap pendidik sangat senang untuk diadili bersama didikannya dan sesungguhnya pendidikan dari Allah Swt adalah Al Qur'an. Dari riwayat-riwayat tersebut sangat jelas utuk kita bahwa penanaman nilai-nilai agama pada masa kecil merupakan dasar pendidikan Islam.Dari ibn Abbas r.a Rasulullah Saw bersabda berikut, Muliakanlah anak-anakmu dan perbaikilah akhlak mereka.

Sejak kecil seorang anak harus diajarkan, dibiasakan, dan dikondisikan untuk melakukan perbuatan terpuji dan tindakan sesuai ajaran agama. Jika seorang anak sejak kecil terbiasa melakukan sutu perilaku buruk akan terbawa hingga ia besar, maka sulit meluruskannya. Artinya, penanaman akhlak kepada anak dimulai sejak 
kecil atau sedini mungkin dan sebaiknya dilakukan oleh setiap orang tua. Janganlah biarkan anak tanpa pendidikan akhlak dan moral. Seharusnya setiap orang tua pada zaman sekarang juga harus memanamkan keimanan yang kuat karena iman itulah yang akan menjadi pelindung di manapun dia berada serta dalam kondisi apapun. ${ }^{10}$

Salah satu yang terpenting adalah akhlak. Dalam pengertian sehari-hari akhlak umumnya artinya disamakan dengan budi pekerti, kesusilaan, sopan santun dalam bahasa Indonesia, dan Tidak berbeda pula dengan arti kata moral. Manusia akan menjadi sempurna jika mempunyai Akhlak terpuji (al- Akhlak al Mahmuda) serta mejauhkan segala yang tercela. Menurut Ibnu Maskawih akhlak adalah keadaan jiwa seseorang yang mendorongnya untuk melakukan perbuatan-perbuatan tanpa melalui pertimabgan pikiran lebih dulu. Karakter yang merupakan suatu keadaan jiwa itu menyebabkan jiwa bertindak tanpa berfikir tau memprtimbangkan secara mendalam.dalam keadaan ini ada dua jenis:

1. Alamiah bertolak dari watak, misalnya pada orang yang mudah sekali marah hanya karena masalah terlalu kecil.

2. Tercipta melalui kebiasaan dan latihan, yang pada mulanya keadaan ini terjadi karena pertimbangan dan dipikirkan kemudian melaluji praktek.

Menurut Al Ghazali akhlak adalah suatu sifat yang tertaanam dalam jiwa dari sifat itu timbul perbuatan-perbuatan dengan mudah, dengan tidak memerlukan pertimbangan pikiran terlebih dahulu. Jadi menurut Ibnu Maskawaih dan Al Ghazali akhlak adalah Sesuatu dalam jiwa yang medorong seseorang mempunyai potensipotensi yang sudah ada sejak lahir. Menurut Ahmad Amin Akhlak adalah kehendak yang dibiasakan dan timbul melalui proses pikir lebih dahulu.Sedang menurut, Abdullah Dirroj akhlak adalah sesuatu kekuatan dalam kehendak yang mntap.MAnusia itu tidak dapat dilihat dari harta, ilmu atau kekuasaannya, tetapi sepenuhnya ditentukan oleh akhlak yakni perbuatan baik atau buruk lebih kepada

\footnotetext{
${ }^{10} \mathrm{http} / / /$ www.dakwatuna.com/2016/04/14/79973/peran-orang-tua-mendidik-anak-alarasulullah/\#ixzz65jKRmdrq
} 
312 | MUSAWA, Vol. 11 No. 2 Desember 2019 : 289 - 318

takwanya serta seberapa jauh nilai-nilai etika menjiwai dan mewarnai segala tindakan.Agama adalah sumber akhlak yang tak pernah kering karena agama memperhatikan dan mengatur setiap perbuatan manusia. Jadi akhlak menjadi salah satu ajaran agama yang penting dalam agama apapun, rasanya semua agama sepakat dan mempunyai pandangan yang sama, yakni semua agama memerintahkan semua pemeluknya berbuat baik dan melarang semua umatnya melakuakn perbuatan jahat.

Allah Swt telah menjadikan perkawinan sesuai menurut syariat islam sebagai penghormatan dan penghargaan yang begitu tinggi terhadap harga diri yang lebih diberikan oleh islam secara khusus untuk manusia di antara mahkluk-mahkluk lainnya. Pernikahan bukan hanya sekadar perkara saling mengikat anatar dua orang insan berlawan jenis. Namun Negara juga sangat berperan sangat penting dalam pengaturannya. Sebab, pernikahan sangat terkait dengan tingkat kesuburan dan dapat berpengaruh pada jumlah manusia. Negara hadir dan terlibat dalam pernikahan Jika tidak diatur, pernikahan akan menimbulkan sejumlah masalah, salah satunya jumlah penduduk serta regenerasi yang dapat berlebihan sehingga memadatkan populasi. Telah disebutkan dalam hadis riwayat Imam Bukhari dari Abdullah bin Mas'ud ra yang mendengar Rasulullah SAW bersabda, Hai pemuda, siapa di antara kalian yang telah mampu maka menikahlah karena menikah itu menundukkan pandangan dan lebih baik untuk kemaluan Namun siapa yang belum mampu maka hendaknya ia puasa, karena itu lebih baik baginya. Juga dalam hadis riwayat An Nasa'i dari Maqbal bin Yasar RA, dari Rasul Saw, nikahilah oleh kalian yang subur dan yang cinta, karena aku ingin banyak keturunan (di akhirat). Dua hadis di atas telah menjelaskan tentang batasan syarat menikah yaitu kemampuan secara finansial meskitK harus kaya. selain itu juga harus menyiapkan mental, yaitu siap menjalankan kewajiban baik sebagai suami maupun istri.

Perkawinan adalah salah satu bentuk khas percampuran antara golongan Arti Az-zawj adalah Sesutu yang berpasangan dengan lainnya. Bila kita mengatakan saya memiliki sepasang merpati maka berarti ada dua ekor merpati yang satu merpati jantan dan satu lagi betina. Semua ada pada Sunnatullah yang telah menetapkan, 
bahwa semua ciptaan Allah diatas bumi selalu berpasangan sebagaimana Firman Allah Swt pada surah Adz Zariyat ayat 49

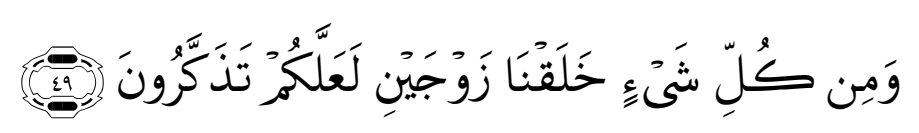

Terjemahannya

Dan segala sesuatu Kami ciptakan berpasang-pasangan supaya kamu mengingat kebesaran Allah.

Manusia diciptakan Allah Swt mempunyai naluri manusiawi yang perlu mendapat pemenuhan.Sementara itu manusia diciptakan Allah Swt untuk mengabdikan dirinya kepada khaliknya dalam segala aktifitas hidupnya. Pemenuhan naluri mahasiswi manusia tujuan kejadiannya, maka Allah Swt mengatur manusia dengan aturan perkawinan. Sebagaimana dalam Surah Al Araf ayat 189-191

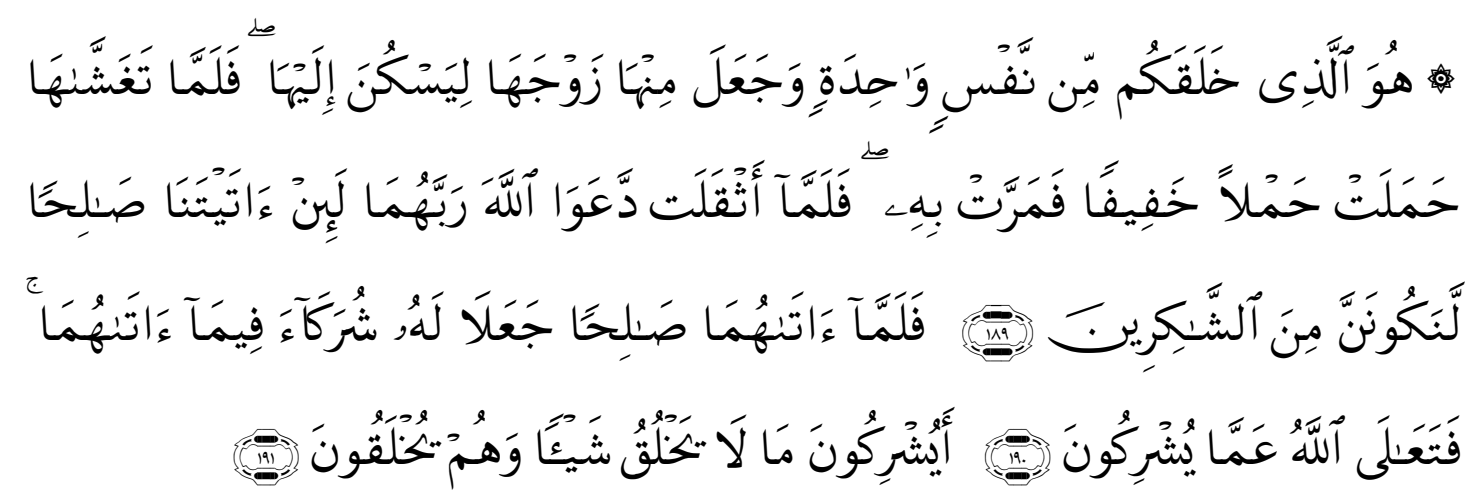

Terjemahannya

Dialah yang menciptakan kamu dari diri yang satu dan dari padanya Dia menciptakan isterinya, agar Dia merasa senang kepadanya. Maka setelah dicampurinya, isterinya itu mengandung kandungan yang ringan, dan teruslah Dia merasa ringan (Beberapa waktu). kemudian tatkala Dia merasa berat, keduanya 
314 | MUSAWA, Vol. 11 No. 2 Desember 2019 : 289 - 318

(suami-isteri) bermohon kepada Allah, Tuhannya seraya berkata: "Sesungguhnya jika Engkau memberi Kami anak yang saleh, tentulah Kami terraasuk orang-orang yang bersyukur".

Salah satu anugerah Allah Swt yang paling berharga adalah akal. Karena, dengan akal manusia bisa berfikir dan bertindak.Pemeliharaan anak pada dasarnya merupakan tanggung jawab orang tua. pemeliharaan ini meliputi dalam berbagai bidang seperti ekonomi, pendidikan dan tanggung jawab. Bila seorang telah memasuki usia dan waktu untuk menikah, maka nikahkan lah dan yakin bahwa rezeki untuk orang menikah itu selalu ada. Sebagaimana dengan firman Allah Swt dalam Al Qur'an pada surah An nur Ayat 32

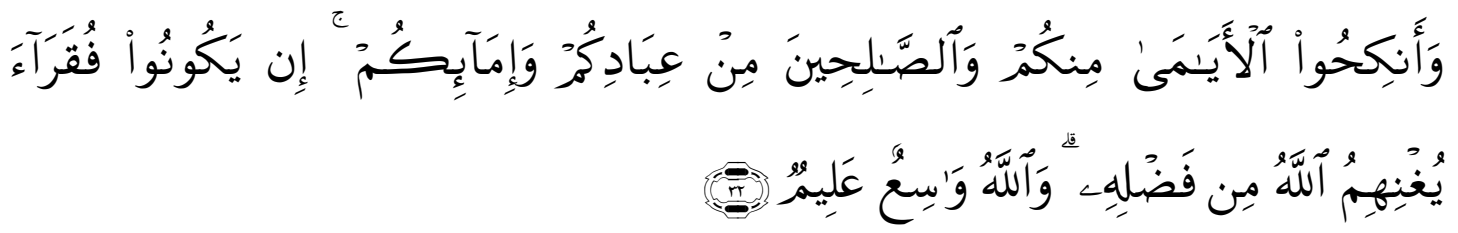

Terjemahannya

Dan kawinkanlah orang-orang yang sedirian diantara kamu, dan orang-orang yang layak (berkawin) dari hamba-hamba sahayamu yang lelaki dan hamba-hamba sahayamu yang perempuan. jika mereka miskin Allah akan memampukan mereka dengan kurnia-Nya. dan Allah Maha Luas (pemberian-Nya) lagi Maha mengetahui.

Sementara pada Hadist Rasulullah Saw adalah sebagian dari kewajiban orang tua terhadap anak-anaknya yaitu mengajarkan menulis atau mendidik, kemudian memberi nama yang baik dan menikahkannya apabila sudah baligh. HR. Ibnu Hibban.

Menikah akan memperbanyak umat Islam, keunggulan banyaknya umat Islam akan memperkuat kekuatan umat sehingga menimbulkan kewibawaan dihadapan umat lainnya. Menikah akan mewujudkan kebanggaan Nabi Saw dihari kiamat kelak dengan banyaknya umatnya. Rasul Saw bersabda,Nikahilah perempuan yang penyayang dan subur, karena sungguh aku bangga dengan banyaknya jumlah kalian di hari kiamat kelak.HR.Ahmad,Annasa-i, dan Abu Dawud. 
Setiap orang tua pasti akan menikahkan anaknya, namun banyak yang menjadi pertimbangan orang tua untuk menikahkan anak. Semua hal itu tidak lain untk kebaikan dan kebhagian anak itu sendiri. Satu hal yang umunya biasa menjadi pertaimbangna adalah agama dari calon menantu tersebut.Aapak yang disukai oleh anaknya itu mempunyai agama yang sama atau menjalankan perintah agama. Bagi orang tua agama adalah peyangga utama dalam membina sebuah rumah tangga. Karena untuk sebuah rumah tangga yang ingin di capai adalah Sakinah, Mawadah dan warahma yang berarti dalam perkawinan itu ada ketenangan,kedamaian ,kebahagiaan dan kenyamanan. Karena, Dengan adanya ketenangan, ketentraman, rasa aman, kedamaian maka keguncangan di dalam keluarga tidak akan terjadi. setiap anggota keluarga dapat memberikan saran pemecahan masalah secara jernih dan menyentuh intinya. Tanpa ketenangan maka sulit masing-masing bisa berpikir dengan jernih, dan mau bermusyawarah, yang ada justru perdebatan, dan perkelahian yang tidak mampu menyelesaikan masalah.

Setelah agama yang menjadi pertimbangan orang tua dalam menikhkan anaknya, mka yang akan menjadi pertimbangan berikut adlah tentng mas depan anaknya, yaitu pekerjaan dan yang akan menjadi sumber masa depan anaknya.bukan berbicara tentang materi atau bersifat matrealistis namu $n$ yang menjadi tuyjuannya adalah setiap orang tua ingin memastikan masa depan anaknya bersama seseorang yang telah dipilih menjadi pasangan dari anaknya. Terutama seorang suami itu bertanggung jawab dan kerja keras demi masa depan keluarganya.Bekerja adalah bentuk amalan ibadah yang memiliki nilai lebih dimata Allah Swt. Karena dengan bekerja, kita menunjukkan usaha kita untuk mendapatkan rezeki sebagaimana yang telah diatur oleh Allah Swt. Dan bekerja dengan niat lillah, dan menafkahi keluarga, Allah Swt janjikan pahala untuk mereka yang bekerja untuk menafkahi keluarga dan ikhlas lillahi ta'ala. Dari Jabir bin Abdillah Nabi bersabda "Wahai umat manusia, bertakwalah engkau kepada Allah, dan tempuhlah jalan yang baik dalam mencari rezeki, karena sesungguhnya tidaklah seorang hamba akan mati, hingga ia benarbenar telah mengenyam seluruh rezekinya, walaupun terlambat datangnya.Maka 
316 | MUSAWA, Vol. 11 No. 2 Desember 2019 : 289 - 318

bertakwalah kepada Allah, dan tempuhlah jalan yang baik dalam mencari rezeki.Hadist Ibnu Majjah.

Latar belakang dari keluarga yang akan menjadi calon pasangan anak adalah sesuatu yang sangat menjadi dasar bagi pertimbangan orang tua untuk menerima dan menjadikan lak-laki yang hendak melmar anak gadis untuk menjadi seorang menantu. Allah Swt sendiri telah menggambarkan bagaimana sosok serta sifat untuk menjadi kepala keluarga yakni terdapat dalam surah An Nisa ayat 34

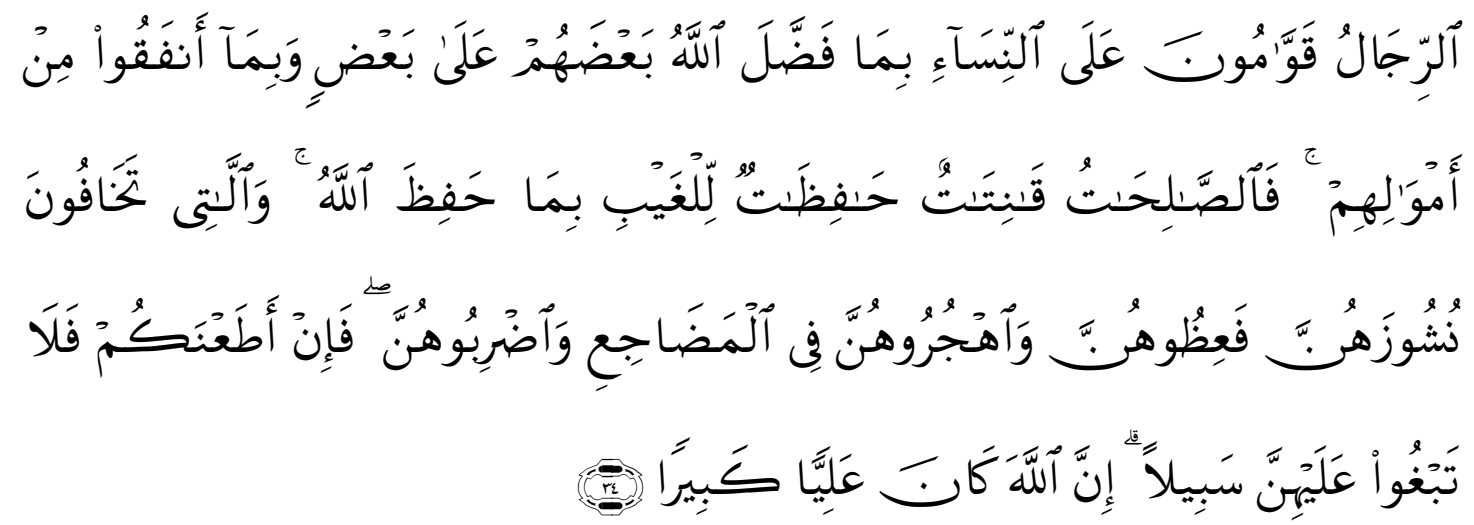

Terjemahannya

Kaum laki-laki itu adalah pemimpin bagi kaum wanita, oleh karena Allah telah melebihkan sebahagian mereka (laki-laki) atas sebahagian yang lain (wanita), dan karena mereka (laki-laki) telah menafkahkan sebagian dari harta mereka.

Bahkan pada surah Maryam ayat 54 - 55 Allah berfirman

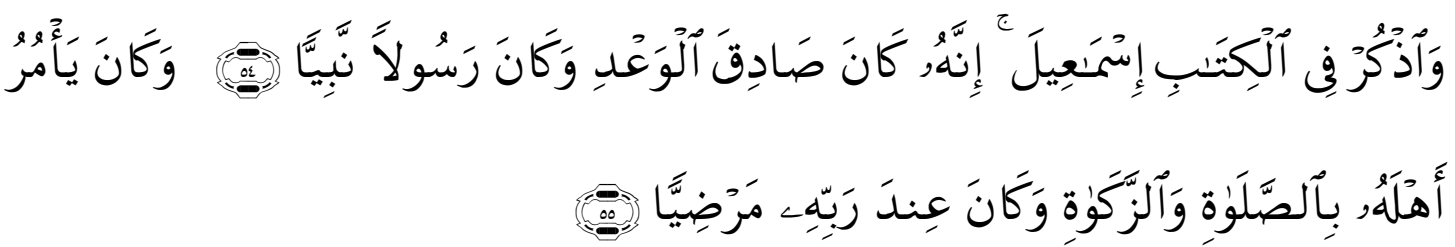

Terjemahannya

Dan Ceritakanlah (hai Muhammad kepada mereka) kisah Ismail (yang tersebut) di dalam Al Quran. Sesungguhnya ia adalah seorang yang benar janjinya, 
dan Dia adalah seorang Rasul dan Nabi. Dan ia menyuruh ahlinya untuk bersembahyang dan menunaikan zakat, dan ia adalah seorang yang diridhai di sisi Tuhannya.

\section{KESIMPULAN}

Kewajiban orang tua itu sangat kompleks, di samping ia harus memenuhi segala kebutuhan anak-anaknya, tetapi mereka juga harus membina anak-anaknya sehingga mereka dapat hidup di tengah-tengah masyarakat dengan mental yang sehat. Sebagai seorang anak, ia wajib mematuhi perintah orangtuanya. Seorang anak harus bisa mengikuti apa yang menjadi aturan dan nasihatnya, selagi tidak bertentangan dengan syariat Islam. Meski begitu, anak pun memiliki hak. Dan sebagai orangtua, memenuhi kewajiban anak merupakan sebuah keharusan.

\section{DAFTAR PUSTAKA}

Abdul Halim, M. Nipan. Mendidik Keshalehan Anak (Akikah, Pemberian Nama, Khitan dan Maknanya), Jakarta: Pustaka Amani, 2001.

Al- Shabbagh, Mahmud. Tuntunan Keluarga Bahagia Menurut Islam. Bandung: Remaja Rosdakarya, 2002.

DEPAG RI, Al-Quran dan Terjemahnya, Bandung: Al-Hikmah, Dipenogoro, 2008.

Hadikusuma, Hilman. Hukum Perkawinan Indonesia. Semarang, Fakultas Hukum Universitas Diponegoro, 1997.

http://www.dakwatuna.com/2016/04/14/79973/peran-orang-tua-mendidik-anak-alarasulullah/\#ixzz65jKRmdrq

https://icc-jakarta.com/2018/07/25/anak-anugerah-sekaligus-amanah-allah-swt/

Khalid, Amru. Berakhlak Seindah Rasululloh. Semarang: Pustaka Nuun, 2007. 
318 | MUSA WA, Vol. 11 No. 2 Desember 2019 : 289 - 318

Notowidagdo, Rohiman, Ilmu Budaya Dasar Berdasarkan Al Qur'an dan Hadits. Jakarta: Raja Grafindo Persada, 2000.

Nuri, Sukamto, Petunjuk Membangun dan Membina Keluarga Menurut Ajaran Islam. Surabaya: Al-Ikhlas, 1981. 